DOI: 10.34015/2523-4552.2019.3.11

Удк 342.92

Яковець I. C.,

доктор юридичних наук,

старший науковий співробітник,

перший заступник директора Державної

установи «Центр пробації»

ORCID ID: 0000-0002-1022-3115

Лук'янченко $\epsilon$. О.,

начальник сектору адміністративних

стягнень Державної установи «Центр

пробації»

\title{
КЛЮЧОВІ ПРОБЛЕМИ ЗАСТОСУВАННЯ СУСПІЛЬНО КОРИСНИХ РОБІТ ЯК ВИДУ АДМІНІСТРАТИВНОГО СТЯГНЕННЯ
}

У статті приділено увагу проблемам застосування адміністративного стягнення у виді суспільно корисних робіт, упровадженого для погашення наявної заборгованості зі сплати аліментів. Зокрема, розглянуто проблемні питання відповідальності осіб, які ухиляються від їх відбування, передбаченої нормами Кодексу України про адміністративні правопорушення та Кримінального кодексу України. Окремо приділено увагу питанню щодо подальшого виконання рішення суду про накладення суспільно корисних робіт стосовно особи, яку було засуджено за злісне ухилення від їх відбування.

Ключові слова: аліменти; боржники; адміністративне стягнення; суспільно корисні роботи.

В статье уделено внимание проблемам применения административного взыскания в виде общественно полезных работ, введенного для погашения имеющейся задолженности по уплате алиментов. В частности, рассмотрены проблемные вопросы ответственности лиц, уклоняющихся от их отбывания, предусмотренной нормами Кодекса Украины об административных правонарушениях и Уголовного кодекса Украины. Отдельно уделено внимание вопросу дальнейшего исполнения решения суда о наложении общественно полезных работ в отношении лиц, которые были осуждены за злостное уклонение от их отбывания.

Ключевые слова: алименты; должники; административное взыскание; общественно полезные работы.

Постановка проблеми. Чинне законодавство чітко визначає, що суспільно корисні роботи як вид ад- міністративного стягнення призначаються за несплату аліментів (ст. 183-1 Кодексу України про адмі- 
ністративні правопорушення (далі КУПАП)). Метою його призначення $\epsilon$ погашення наявної заборгованості зі сплати аліментів, але, враховуючи реальний стан застосування суспільно корисних робіт, на наш погляд, недосконалим є законодавство у цій сфері.

На сьогоднішній день залишаються неврегульовані питання щодо правовідносин, які виникають між власником підприємства та порушником за місцем відбування суспільно корисних робіт; форми власності об'єктів, на яких порушники відбуватимуть призначені судом суспільно корисні роботи; джерел, з яких власники підприємств повинні оплачувати такі роботи; оподаткування нарахованої плати та ін.

На наш погляд, низка вищевказаних проблем, не дозволяє досягти мети адміністративного стягнення, яка $\epsilon$ мірою відповідальності та застосовується для виховання особи, яка вчинила адміністративне правопорушення, у дусі додержання законів України, поваги до правил співжиття, а також запобігання вчиненню нових правопорушень як самим порушником, так і іншими особами (ст. 23 КУпАП) та не дає змогу працівникам уповноважених органів 3 питань пробації у низці випадків безперешкодно виконувати судове рішення про застосування суспільно корисних робіт.

Аналіз останніх досліджень i публікацій темі застосування та впровадження суспільно корисних робіт як виду адміністративного стягнення не приділяється достатньо уваги в дослідженнях. Тому метою статті $є$ саме аналіз і формування власних висновків щодо ефективності такого стягнення, зважаючи на практику та тенденції, що склалися.

Постановка завдання. Охарактеризувати проблемні аспекти впровадження суспільно корисних робіт та виконання рішень суду про їх застосування. Зокрема дослідити обставини, що фактично унеможливлюють процес притягнення до відповідальності осіб, які ухиляються від відбування накладеного на них судом стягнення.

Виклад основного матеріалу. 3 прийняттям Закону України «Про внесення змін до деяких законодавчих актів України щодо посилення захисту права дитини на належне утримання шляхом вдосконалення порядку примусового стягнення заборгованості зі сплати аліментів» від 09 грудня 2017 року № 2234-VIII ст. 24 КУпАП доповнено таким видом адміністративного стягнення, як суспільно корисні роботи.

Зазначений Закон було розроблено для забезпечення належного виконання рішень щодо стягнення аліментів і зменшення наявної заборгованості. Ним було передбачено нові засоби примусового виконання рішень до боржника, який не сплачує аліменти більше ніж шість місяців [1].

Відповідно до ст. 31-1 КУпАП, суспільно корисні роботи полягають у виконанні особою, яка вчинила адміністративне правопорушення, оплачуваних робіт, вид яких та перелік об'єктів, на яких порушники повинні виконувати ці роботи, визначає відповідний орган місцевого самоврядування [2].

Постанова про накладення адміністративного стягнення у виді суспільно корисних робіт звертається до виконання судом, який iї виніс. 
Саме на цьому етапі роботу починає орган пробації, оскільки відповідно до ст. 325-1 КУПАП та п. 11.1. Порядку виконання адміністративних стягнень у вигляді громадських робіт, виправних робіт та суспільно корисних робіт, затвердженого наказом Міністерства юстиції України від 19 березня 2013 року № 474/5, виконання стягнення у вигляді суспільно корисних робіт покладається на уповноважений орган з питань пробації [3].

Майже дворічна практика існування такого виду стягнення фактично довела не лише його неефективність, а й шкідливість. Його введення породило значно більше проблем у практиці ніж сприяло розв'язанню проблеми несплати аліментів.

Так, органи місцевого самоврядування повинні визначати види оплачуваних робіт і об'єкти для їх виконання. Нині вони зобов'язані приймати на роботу та оплачувати 3 місцевих бюджетів працю осіб, які мають заборгованість 3 аліментів, додатково перераховуючи кошти на оплату судового збору та оплату послуг державних виконавців за складений протокол і перерахування коштів. Це не лише «відбирає» робочі місця у населення, а й примушує місцеві органи влади створювати зайві та не потрібні робочі місця на комунальних підприємствах, оскільки їх чисельність зумовлена не потребами підприємства, а лише числом осіб, яким призначено це стягнення. У значній кількості підприємств коштів на оплату праці цієї категорії взагалі бракує і рішення суду про накладення стягнення у виді суспільно корисних робіт тривалий час не виконуються.

Крім того, не зовсім зрозуміле визначення «об'єкта» для відбування суспільно корисних робіт. Як свідчить практика, цей термін слід розуміти як перелік підприємств, установ, організацій, на яких порушники виконуватимуть суспільно корисні роботи, проте законодавцем чітко не було визначено форму власності таких об'єктів, у зв'язку з чим виникає чимало запитань.

Також, власникам підприємств не зрозуміло яким чином оформлювати осіб, які з'явилися за направленням для відпрацювання призначеного судом стягнення. Так, правовідносини, що виникають між власником підприємства та порушником, на якого накладено адміністративне стягнення у виді суспільно корисних робіт, мають низку ознак, притаманних трудовим відносинам, однак чинним законодавством не передбачено укладання трудового чи цивільно-правового договору.

Зокрема, набула поширення практика оформлення порушників на період відбування адміністративного стягнення відповідно до норм трудового законодавства, укладаючи 3 ними трудовий або цивільноправовий договір, що в результаті призводить до порушення власниками підприємств ст. 128 КЗпП України (Обмеження розміру відрахувань із заробітної плати), оскільки кошти за оплату виконання суспільно корисних робіт повним обсягом перераховуються на відповідний рахунок органу державної виконавчої служби.

У разі ухилення особи від відбування адміністративного стягнення у виді суспільно корисних робіт вона підлягає притягненню до адміністративної відповідальності, що законодавчо закріплено у ст. 325-4 КУПАП. 
Досліджуючи це положення, виявлено, що санкція вищезазначеної статті передбачає накладення адміністративного стягнення у виді адміністративного арешту до 10 діб, однак реалізація цієї санкції часто $є$ неможливою. Зокрема, фактично неможливим $€$ притягнення до адміністративної відповідальності за ухилення від відбування адміністративного стягнення у виді суспільно корисних робіт жінки, яка має дитину віком до 12 років, оскільки до цієї категорії осіб адміністративний арешт не може бути застосований відповідно до ст. 32 КУпАП, а санкція ст. 1832 КУпАП не містить альтернативного виду стягнення. Тобто надсилання протоколів про адміністративне правопорушення відносно жінок, які мають дітей віком до 12 років, призведе до відмови суду притягати винних до відповідальності за ухилення від відбування суспільно корисних робіт, як наслідок, особа може продовжувати ухилятися від відбування суспільно корисних робіт та не буде нести відповідальність за це.

Злісне ухилення, за яке вже передбачено кримінальну відповідальність (ст. 389-2 КК України), на думку законодавця - це продовження ухилення від відбування суспільно корисних робіт особою, яку притягнуто до адміністративної відповідальностi [4].

Закріплення дій, що нині передбачені ст. 389-2 КК України (Злісне ухилення від відбування адміністративного стягнення у виді суспільно корисних робіт), як самостійний склад злочину, на нашу думку, породжує низку негативних наслідків у правозастосуванні.

Винесення обвинувального вироку судом відносно осіб, які злісно ухиляються від відбування адміністративного стягнення у виді суспільно корисних робіт, породжує правову колізію, оскільки а ні кримінальним, а ні адміністративним законодавством не передбачено процедури поглинання чи складання кримінальних покарань $з$ адміністративними стягненнями, тому постанови суду про накладення адміністративного стягнення підлягають подальшому виконанню.

Як свідчить практика, винесення вироку відносно порушників не впливає на їх правосвідомість і вони продовжують ухилятися від відбування суспільно корисних робіт.

Таким чином, ухилення особи від відбування адміністративного стягнення у виді суспільно корисних робіт $\epsilon$ триваючим правопорушенням, яке має місце там, де протиправне діяння (дія чи бездіяльність) триває безперервно протягом певного часу до моменту його припинення.

у теорії адміністративного права «триваючими» визначаються правопорушення, які, почавшись 3 якоїсь протиправної дії чи бездіяльності, здійснюються потім безперервно шляхом невиконання обов'язку. Отже, 3 урахуванням змісту норм українського законодавства та практики Європейського суду з прав людини (далі - ЄСПЛ), зазначені норми унеможливлюють застосування ст. 389-2 КК України стосовно особи, яка злісно ухиляється від відбування адміністративного стягнення у виді суспільно корисних робіт, оскільки ЄСПЛ неодноразово у своїх рішеннях констатував про недопустимість притягнення до юридичної відповідальності одного виду за одне й те саме правопорушення. 
Крім того, чинні норми кримінального та адміністративного права сформовано законодавцем 3 урахуванням конституційного принципу «non bis in idem», зміст якого полягає в забороні притягати двічі до юридичної відповідальності одного виду за одне й те саме правопорушення (ст. 61 Конституції України, ч. 1 ст. 3 КК України, ч. 1 ст. 19 КПК України), а тому і виникає запитання: як реагувати на подальше ухилення осіб, від відбування призначених судом суспільно корисних робіт після винесення обвинувального вироку відносно них?

Незначними є й суми, які потенційно може заробити порушник, котрі не покривають всієї заборгованості або хоча б ії значної частини. Так, відповідно до ст. 325-1 КУпАП, за виконання суспільно корисних робіт порушнику нараховується плата за виконану ним роботу. Оплата праці здійснюється погодинно за фактично відпрацьований час у розмірі не меншому, ніж установлений законом мінімальний розмір оплати праці.

За статистикою Державної установи «Центр пробації» за три квартали поточного року в уповноважених органах 3 питань пробації пройшло по обліку 7759 осіб, на яких накладено адміністративне стягнення у виді суспільно корисних робіт. Водночас динаміка відпрацювання особами, на яких накладено це стягнення, свідчить про їх неефективність, оскільки тільки 3523 особи, знято з обліку в зв'язку з відбуттям повним обсягом призначеної судом кількості годин суспільно корисних робіт (тобто лише 45\% від усієї кількості, які пройшли по обліку).

Таким чином, мета цього виду стягнення, яка полягає у погашенні заборгованості зі сплати аліментів, досягається менш ніж у більшості випадків. За нашими підрахунками у середньому за виконання 7759 постанов суду про накладення суспільно корисних робіт могло б бути перераховано понад 20 мільйонів гривень, однак за виконані 3523 рішень суду перераховано не більше як 8-9 мільйонів гривень.

Висновки. Варто акцентувати увагу на неспроможності під час застосування ст. 183-1 КУПАП, ст. 183-2 КУПАП та ст. 389-2 КК України досягнення мети адміністративної або кримінальної відповідальності та проблемі застосування ст. 389-2 КК України, що полягає, зокрема у їі неефективності та колізій у правозастосуванні.

Відповідно гуманізація кримінальної відповідальності за ухилення від сплати аліментів, відмова від карального характеру контролю за ухиленням від їх сплати та запровадження майнових санкцій для боржників дозволить створити сприятливіше середовище для процесу погашення заборгованості зі сплати аліментів. Це питання заслуговує на подальше вивчення у наукових працях та дослідженнях.

\section{Список використаних джерел}

1. Про внесення змін до деяких законодавчих актів України щодо посилення захисту права дитини на належне утримання шляхом вдосконалення порядку примусового стягнення заборгованості зі сплати аліментів: Закон України від 07.12.2017 р. 
№ 2234-VIII. URL: http://zakon0.rada.gov.ua/laws/show/2234-19 (дата звернення: 10.11.2019)

2. Кодекс України про адміністративні правопорушення. URL: https://zakon.rada.gov.ua/laws/show/80731-10. (дата звернення: 10.11.2019).

3. Про затвердження Порядку виконання адміністративних стягнень у вигляді громадських робіт, виправних робіт та суспільно корисних робіт. Наказ Міністерства юстиції України від 19.03.2013 р. № 474/5. URL: http://zakon0.rada.gov.ua/ laws/show/z0457-13. (дата звернення: 10.11.2019).

4. Кримінальний кодекс України. URL: https://zakon2.rada.gov.ua/laws/show/ 2341-14. (дата звернення: 10.11.2019).

\section{References}

1. Pro vnesennya zmin do deyakih zakonodavchih aktiv Ukrayini shodo posilennya zahistu prava ditini na nalezhne utrimannya shlyahom vdoskonalennya poryadku primusovogo styagnennya zaborgovanosti zi splati alimentiv: Zakon Ukrayini vid 07.12.2017 r. № 2234-VIII. URL: http://zakon0.rada.gov.ua/laws/show/2234-19 (data zvernennya: 10.11.2019) [in Ukrainian].

2. Kodeks Ukrayini pro administrativni pravoporushennya. URL: https://zakon.rada.gov.ua/laws/show/80731-10. (data zvernennya: 10.11.2019) [in Ukrainian].

3. Pro zatverdzhennya Poryadku vikonannya administrativnih styagnen u viglyadi gromadskih robit, vipravnih robit ta suspilno korisnih robit. Nakaz Ministerstva yusticiyi Ukrayini vid 19.03.2013 r. № 474/5. URL: http://zakon0.rada.gov.ua/laws/show/z0457-13. (data zvernennya: 10.11.2019) [in Ukrainian].

4. Kriminalnij kodeks Ukrayini. URL: https://zakon2.rada.gov.ua/laws/ show/2341-14. (data zvernennya: 10.11.2019) [in Ukrainian].

I. Iakovets, Doctor of Law, Senior Scientific Researcher, First Deputy Head of he Public In i u ion «Cen e of $P$ ob ion»

ORCID ID: 0000-0002-1022-3115

Y. Lukianchenko, Head of the Administrative Penalties Unit of the Public In $i$ ion «Cen e of $P$ ob ion»

ORCID ID: 0000-0002-1022-3115

\section{Key problems of execution of the socially useful works as a type of the administrative penalties}

The article is focused on the problems of execution of the administrative penalties in the form of the socially useful works, which are introduced for the purpose of paying the alimony arrears. In particular, the problematic issues of responsibility (under the norms of the Administrative Offenses Code and the Criminal Code of Ukraine) of those persons, who evade such penalties, are considered.

Besides, the problematic aspects of the socially useful works introduction are considered and described. The circumstances that actually make it impossible to prosecute those persons, who evade the penalties, which have been imposed by courts, are revealed. Particular attention is paid to the issue of further execution of 
the courts' decisions to impose the socially useful works by the persons, who had been previously convicted for the malicious evasion.

Taking into consideration the case study results, it has been established that the humanization of the criminal liability for the alimony evasion, the renunciation of the punitive nature of the control over the evasion of the alimony payments and the imposition of the property sanctions against debtors create more favorable environment for the process of paying the alimony arrears.

Keywords: alimony; debtors; administrative responsibility; socially useful works. 